\title{
A Study on Interactive-Based Learning Media to Strengthen the Profile of Pancasila Student in Elementary School
}

\author{
Yayuk Hidayah ${ }^{1)}$, Suyitno ${ }^{2)}$, Yusuf Faisal Ali ${ }^{3)}$ \\ Department of Primary School Education, Universitas Ahmad Dahlan, Jl. Kapas No. 9, Semaki, \\ Umbulharjo, Daerah Istimewa Yogyakarta 55166, Indonesia ${ }^{1,2)}$ \\ Department of Pancasila and Citizenship Education, STKIP Pasundan, Cimahi, Jl. Permana No.32B, \\ Citeureup, Kec. Cimahi Utara, Kota Cimahi, Jawa Barat 40512, Indonesia ${ }^{3)}$ \\ yayuk.hidayah@pgsd.uad.ac.id
}

\begin{abstract}
This study aimed to determine the interactive-based learning media to strengthen the profile of Pancasila students in elementary schools. This type of research was literature study. The results showed that interactive-based learning media to strengthen the profile of Pancasila students in elementary schools can increase motivation in learning by the emergence of independent characters as a part of the character in the profile of Pancasila students in elementary schools. It was also seen as a facility in active learning for students to strengthen the profile of Pancasila students in elementary schools as well as to lead to a tendency to have a good character component. In addition, this learning media eased students to understand learning in term of strengthening the profile of Pancasila students in elementary schools by the emergence of the character of critical and creative reasoning. The use of the interactive -based learning media could build conducive and enjoyable learning atmosphere.
\end{abstract}

Keywords: National Cultural Diversity, Interactive Learning Media, Pancasila Student Profile, Elementary School

\begin{abstract}
Abstrak. Penelitian ini bertujuan untuk mengetahui media pembelajaran berbasis interaktif untuk memperkuat profil pelajar pancasila di Sekolah Dasar. Jenis penelitian ini ialah kualitatif studi literatur. Hasil penelitian menunjukan jika media pembelajaran berbasis interaktif untuk memperkuat profil pelajar pancasila di Sekolah Dasar dapat 1) Meningkatkan motivasi dalam pembelajaran dengan munculnya karakter mandiri sebagai bagian karakter dalam profil pelajar pancasila di Sekolah Dasar. 2) Menjadi fasilitas dalam belajar aktif bagi siswa untuk memperkuat profil pelajar pancasila di Sekolah Dasar ialah mengarah pada kecendrungan kepemilikan komponen karakter yang baik. 3) Memudahkan siswa dalam memahami pembelajaran untuk memperkuat profil pelajar pancasila di Sekolah Dasar ialah dengan munculnya karakter nalar kritis dan kreatif. Penggunaan media pembelajaran berbasis interaktif dapat membangun suasana pembelajaran yang kondusif dan menyenangkan.
\end{abstract}

Kata Kunci: Keragaman Budaya Bangsa, Media Pembelajaran Interaktif, Profil Pelajar Pancasila, Sekolah Dasar 


\section{INTRODUCTION}

Interactive learning media in elementary schools has an important role to support learning achievement that can increase students' knowledge in elementary schools with their unique characteristics. Cosner, (2020) state that at the school level, individual critical engagement provides an opportunity to reflect on appropriate strategies and practices. Therefore, interactive learning media in elementary schools can encourage changes in the learning process in elementary schools, so that they can get results in accordance with learning objectives.

The use of interactive learning media in the practice of learning in elementary schools is still one of the criteria/standard in the success of the learning process. Wahab (2016) states that interactive learning is learning that creates an educative learning atmosphere with interaction between teachers, students and their environment. (Levy \& Gamboa (2013) also define that media in interactive learning is a media that is visually useful in delivering information interactively.

Interactive learning can significantly influence students' perceptions of the learning process. Similarly, Francisco, José, and Carmen (2012) argue that interactive learning confirms the pedagogical effectiveness of the software designed based on information communication technology (ICT). Teaching and learning methods are often ineffective and result in conditions that can make students despair in learning. Facing this situation, for elementary schools, interactive learning becomes urgent, because it can connect students with teachers, students and their environment.

The fourth paragraph of the Preamble to the 1945 Constitution emphasizes that education aims to educate the life of the nation. Strengthening the profile of Pancasila students for Elementary Schools is an effort to educate nation's life, considering its scope that touches various dimensions of learning for students. According to Hidayah, Trihastuti, and Dewie (2021), improving ideological intelligence of students can use various strategies and methods. In relation to strategies and methods in improving students' ideological intelligence through the learning process, Hidayah et al (2020) explained that in elementary school, appropriate strategies and methods are needed with the characteristics of students.

Previous research has shown that the development of interactive learning media for elementary schools is needed, especially in the matter of national cultural diversity in the territory of Indonesia as long as it is associated with strengthening the profile of Pancasila students for elementary schools, whereas the Minister of Education and Culture of Indonesia Nadiem Makarim explained that the Pancasila student profile makes students more ready to learn about new things. Puspita (2020) has quoted six characteristics of the profile of Pancasila students from the Elementary 
School Directorate page (2020), namely 1) faith, fear of God the Almighty, and noble character, 2) global diversity, 3) mutual cooperation, 4) independent, 5) critical reasoning, and 6) creative.

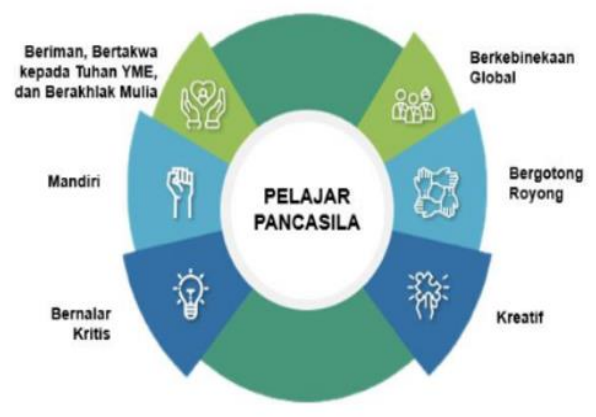

Figure 1. Pancasila Student Profile Source: (Directorate of Primary Schools, 2020)

The profile of Pancasila Student is one of the successes of the driving school. Nadiem Makarim explained that six characters in the Pancasila Student Profile can be described as follows. Noble character can lead to understanding moral values, creativity is related to problem solving, mutual cooperation is related to how to work together, global diversity is related to respect for diversity, critical reasoning is related to the ability to analyze problems, and Pancasila student independency is related to ownership of independence (kompas.com, 2020). The profile of Pancasila students is relevant with the integrity of Indonesia as a Nation. Sulistyarini (2015) emphasizes that the existence of a nation is determined by their character. The profile of Pancasila student is an ethical value for young people in Indonesia. According to Lickona (1991), understanding of ethical values is an understanding of character education.

Suresh and Clinton (2021) states that the identification process strongly conditions and determine the acceptance of the changes being introduced. Technically, the profile of Pancasila student is also a "social movement" that is in line with the development of the nation's character by referring to Pancasila as the basis of the state.

This study aimed to find out interactivebased learning media to strengthen the profile of Pancasila students in elementary schools. The theoretical benefit of this study was to increase knowledge about interactive-based learning media used to strengthen the profile of Pancasila students in elementary schools, while it could be practically used as a basis for relevant further research.

The novel aspect of this study was that it offered a solution to the problem of strengthening the profile of Pancasila students in elementary schools. It also provided a comprehensive picture of interactive-based learning media to strengthen the profile of Pancasila students in elementary schools, and contributing to the development of Pancasila and Citizenship Education in elementary schools, especially a study on the profiles of Pancasila students in elementary schools.

\section{RESEARCH METHODS}

This study was a literature study with a critical descriptive method emphasized on 
deep analysis on existing sources. Soejono \& Abdurrahman (1999) (1999) emphasized that critical descriptive is a depth interpretation to find the thesis and anti-thesis. The qualitative perspective used in this study referred to Moleong, that qualitative research does not employ words and not in the form of numbers (Moleong, 2011)

The objects in this study were research articles, research reports, books, and other transcripts, both printed and online version that discussed interactive-based learning for the profile of Pancasila student in elementary schools. We used documentation technique to collect data as referring to Nazir (2013). The use of documentation technique was to search in various publishers, such as Gooogle Schoolar, ERIC, SAGE, JSTOR and others by using some keywords, namely interactivebased learning, profile of Pancasila student, and elementary school. In analyzing the data, we carried out some ways, namely 1) descriptive data analysis in the form of compiling data for later analysis (Arikunto, 2006)2) content analysis is based on Hostli's opinion in (Muhajir, 1996), and 3) critical analysis model by (Muhajir, 1996).

\section{DISCUSSION}

Increasing Motivation in Learning to Strengthen the Profile of Pancasila Students in Elementary Schools

In this study, we found that interactivebased media can increase motivation of students in learning that could help to strengthen the profile of Pancasila students in elementary schools. A. A. Wahab \& Sapriya (2011) state that motivation directs a person to his goal, so that interactive-based media is a way of organizing values and learning objectives to encourage students' motivation in learning.

Students' motivation increases with interactive-based media will be reciprocity in achieving learning goals; one of which is to strengthen the profile of Pancasila students in elementary schools in accordance with the ideals of the state in realizing an independent nation with integrity, character and sovereignty.

This study also resulted that students' motivation in learning by using interactivebased learning media could connect students' ideas that could be interpreted in character and identity as citizens. One of the characteristics of Pancasila students was independence that could be strengthened by learning motivation students. It was beneficial that students could independently realize the situation they were in. Somehow, the intrinsic motivation that comes from students themselves will lead them to achieve the desired learning goals in line with independent character in the profile of Pancasila students. 


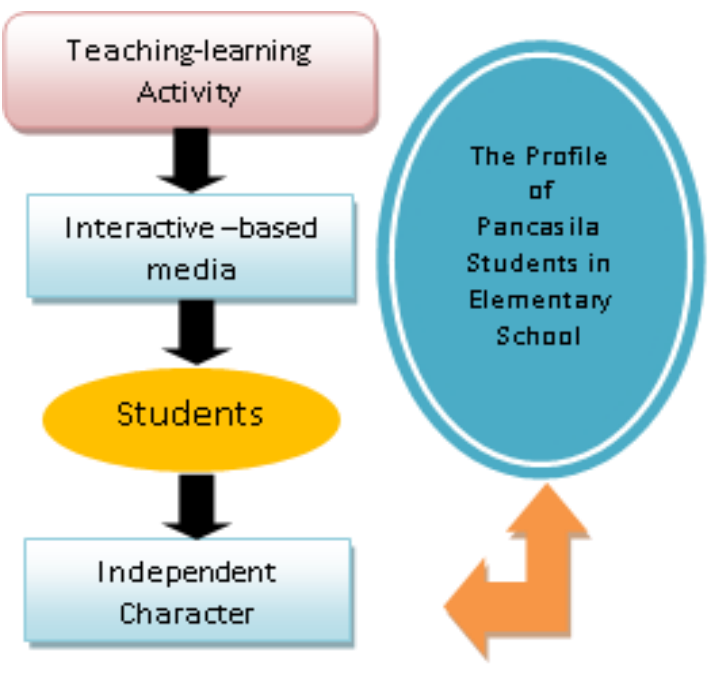

Figure 2. Students' Motivation to Strengthen the Profile of Pancasila Students in Elementary Schools

Character is a way of thinking and behaving that can reflect the characteristic of family, community and state's life (Wibowo, 2011). Figure 2 addressed that in the process of achieving these learning goals, there were civic values that could reinforce students as citizens with national values; one of which was the profile of Pancasila students.

Increasing motivation in learning, the profile of Pancasila students was expected to help in the implementation of ideal elementary school education. Hidayah et al (2020) stated that elementary school students have unique and different characteristics from each other. By usinginteractive-based learning media, the position of the media is as an infrastructure in learning so that it can affect learning outcomes. From this it can be understood thatOne of the motivations in learning to strengthen the profile of Pancasila students in elementary schools is that it can be assisted by the use of interactive-based learning media.

The profile of Pancasila students in elementary school could be also a civic moral for students. Irwin, Jensen, \& Jones (2012) state that criticism is a recurring and significant characteristic of public engagement exercises. In the learning process, the student's learning motivation was presented in the use of interactive-based learning media that could helps students to position themselves as citizens that might be able to also train other students in public engagement exercise.

\section{Being a Facility in Active Learning}

In this matter, we found that interactivebased media could facilitate active learning for students to strengthen the profile of Pancasila students in elementary schools. (Lombardi \& Shipley (2021) state that active learning constructs are used to communicate alternatives and serve purposes in classroom practice, so that interactive-based learning media is a tool in communicating the values of the profile of Pancasila students in elementary schools.

The emphasis on interactive-based learning media was that it could facilitate students to strengthen their Pancasila profile that could also encourage a good character component in themselves. Lickona (1991) explains that there are three types of components of good character, namely moral 
knowledge, moral awareness, and knowledge of moral values.

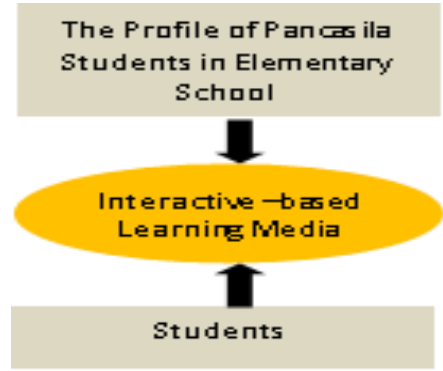

Figure 3. Interactive-based Learning Media Facilitated Students to Strengthen their Pancasila Profile

Figure 3 indicated that interactive-based learning media could involve students' activeness in learning. Interactive-based learning media becomes a facility in students' active learning to strengthen their Pancasila profile. Barnawi. \& Arifin (2013) emphasize that learning process requires facilities to be smooth and orderly. Therefore, in achieving the profile of Pancasila students in elementary schools, interactive-based learning media was an alternative solution in terms to maximize students' activeness in learning.

Students' activeness in learning with reinforcement on the profile of Pancasila students was one of terms to accomodate passive attitude of students in learning. Nicol, Owens, Le Coze, MacIntyre, \& Eastwood, (2017) state that technology-based active learning accommodates leadership. This evidence reflects the collaborative attitude and cooperation as well as gotong royong that become one of the characters in the profile of Pancasila students.
Furthermore, learning facilities resulting from the implementation of interactive-based learning media will activate students' learning and create collaborative situations among students. Cosner (2020) states that active learning design is recognized as an element to strengthen learning design. Therefore, the collaborative attitude among students that reflects students' Pancasila profile has become the forerunner in realizing a good and intelligent citizen.

\section{Making It Easier for Students to Understand Learning}

We found that interactive-based media could facilitate students to understand learning subjects for the reinforcement of the profile of Pancasila students in elementary schools. active learning is a shift from exposition instruction which has a tendency to make students bored or passive. (Mourad, A, Jurjus, A, Hussein, 2016). Besides, it can also ease students to build creative characters and critical reasoning. Fettahlıŏlu, P., Kaleci, (2018) confirm that critical thinking is an important educational life skill, so that by using interactive learning, students would be easier to learn analysis, comparison and involvement in critical and creative thinking as a part of students' Pancasila profile.

The convenience of students in understanding learning to bring out creative characters and critical reasoning is a place for students to develop various potentials within 
themselves. Zandvakili, Washington, Gordon, Wells, \& Mangaliso (2019) state that as students construct and interrogate their concept maps, they also see the representation of their own thoughts for the first time. Thus, there is a harmonious, uniform and harmonious continuity between students' learning process using interactive -based learning media and strengthening the profile of Pancasila students.

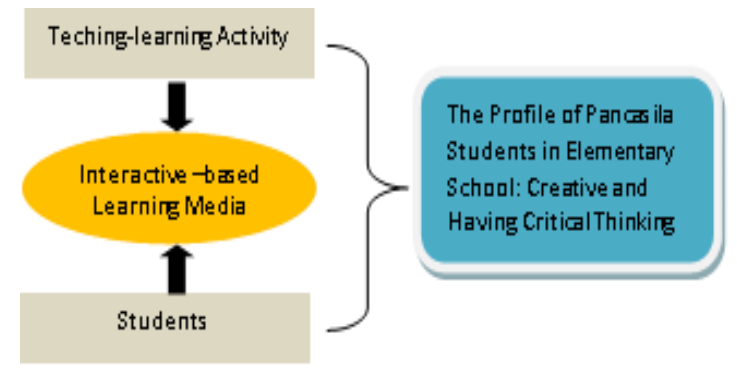

Figure 4. The Convenience of Students in Understanding Learning Subject by Using

Interactive -based Learning Media

In Figure 4, we can see that interactive -based learning media will later form attitudes, such as good behaved, responsible, critical and creative as well as having a broad insight. Shaw (2014) states that critical reframing of thinking requires that students to take an active role and critical action in education to pursue changes. Therefore, some efforts to strengthen the profile of Pancasila students could be planned, organized and sustainable.

Today's social problems are complex and require critical thinking. (Heinrich, Habron, Johnson, \& Goralnik, 2015) The critical and creative character that emerged in the convenience of learning in using interactive -based learning media was in line with strengthening the profile of Pancasila students that could accommodate students to be community leaders in their lives.

\section{CONCLUSION}

We could conclude some significances of interactive -based learning media, namely 1) increasing motivation in learning by the emergence of independent characters as part of the character in the profile of Pancasila students in elementary schools, 2) being a facility in active learning to strengthen the profile of Pancasila students in elementary schools that could result a good character, and 3) making it easier for students to understand learning as well as to strengthen the profile of Pancasila students in elementary schools through the emergence of critical and creative reasoning.

Thank you to LPPM UAD for the Academic Year 2020/2021 for funding this research through the Beginner Lecturer Research (PDP) scheme. Thanks to Dr. Sri Tutur Martaningsih, M.Pd who has guided this research to success.

\section{REFERENCES}

[1] Arikunto, S. (2006). Prosedur Penelitian Suatu Pendekatan Praktek. Jakarta: PT. Rineka Cipta.

[2] Barnawi., \& Arifin, M. (2013). Mengelola Sekolah Berbasis Entrepreneurship. Yogyakarta: Ar Ruzz Media.

[3] Cosner, S. (2020). A Deeper Look Into Next Generation Active Learning Designs for Educational Leader Preparation. Journal of Research on Leadership Education, 15(3), 
167-172.

https://doi.org/10.1177/1942775120936301

[4] Direktorat Sekolah Dasar. (2020). Profil Pelajar Pancasila. Diambil dari http://ditpsd.kemdikbud.go.id/hal/profilpelajar-pancasila

[5] Fettahlığlu, P., Kaleci, D. (2018). Online argumentation implementation in the development of critical thinking disposition. Journal of Education and Training Studies, (6), 127-136.

[6] Francisco, A., José, M., \& Carmen, M. (2012). Interactive learning in operations management higher education: Software design and experimental evaluation. International Journal of Operations \& Production Management, 32(12), 1395-1426. https://doi.org/10.1108/01443571211284160

[7] Heinrich, W. F., Habron, G. B., Johnson, H. L., \& Goralnik, L. (2015). Critical Thinking Assessment Across Four SustainabilityRelated Experiential Learning Settings. Journal of Experiential Education, 38(4), 373-393.

https://doi.org/10.1177/1053825915592890

[8] Hidayah, Y., Dewi, D. A., \& Trihastuti, M. (2021). The adaptation of scientific reasoning of prospective teachers for primary education in the perspective of civic science. Jurnal Civics: Media Kajian Kewarganegaraan. https://doi.org/10.21831/jc.v18i1.36916

[9] Hidayah, Y., Halimah, L., Trihastuti, M., Dewie, D. A., Feriandi, Y. A., \& Dianasari, D. (2020). How Did Prospective Elementary School Teacher Learn Citizenship Education during the Pandemic Covid-19 in Indonesia? IJERI: International Journal of Educational Research and Innovation, 15, 373-387.

[10] Irwin, A., Jensen, T. E., \& Jones, K. E. (2012). The good, the bad and the perfect: Criticizing engagement practice. Social Studies of Science, 43(1), 118-135. https://doi.org/10.1177/0306312712462461

[11] Kompas.com. (2020). Apa Itu Pelajar Pancasila, Tujuan Sekolah Penggerak dari Nadiem Makarim. kompas.com. Diambil dari https://www.kompas.com/edu/read/2020/03/ 12/093000071/apa-itu-pelajar-pancasila- tujuan-sekolah-penggerak-dari-nadiemmakarim?page $=$ all

[12] Levy, S., \& Gamboa, F. (2013). Quality Requirements for Multimedia Interactive Informative Systems. Journal of Software Engineering and Applications, 06, 416-425. https://doi.org/10.4236/jsea.2013.68051

[13] Lickona., T. (1991). Educating for Character: How Our Schools Can Teach Respect and Responsibility. New York: Bantam.

[14] Lombardi, D., \& Shipley, T. F. (2021). The Curious Construct of Active Learning. Psychological Science in the Public Interest, 22(1), 8-43. https://doi.org/10.1177/1529100620973974

[15] Moleong, L. J. (2011). Qualitative Research Methods. Revised Edition. Bandung: PT. Remaja Rosdakarya.

[16] Mourad, A, Jurjus, A, Hussein, I. (2016). The what or the how: a review of teaching tools and methods in medical education. Med Sci Edu, 723-728.

[17] Muhajir, N. (1996). Metodologi Penelitian Kualitatif. Yogyakarta: Rake Sarasin.

[18] Nazir, M. (2013). Metode Penelitian. Bogor,: Ghalia Indonesia.

[19] Nicol, A. A. M., Owens, S. M., Le Coze, S. S. C. L., MacIntyre, A., \& Eastwood, C. (2017). Comparison of high-technology active learning and low-technology active learning classrooms. Active Learning in Higher Education, 19(3), 253-265. https://doi.org/10.1177/1469787417731176

[20] Puspita, R. (2020). Mendikbud Jelaskan Anak Memiliki Profil Pelajar Pancasila. Republika.co.id. Diambil dari https://www.republika.co.id/berita/q19s14428/ mendikbud-jelaskan-anak-memiliki-profilpelajar-pancasila

[21] Shaw, R. D. (2014). How Critical Is Critical Thinking? Music Educators Journal, 101(2), 65-70.

https://doi.org/10.1177/0027432114544376

[22] Soejono, \& Abdurrahman. (1999). Metode Penelitian Suatu Pemikiran dan 
Penerapannya. Jakarta: Reneka Cipta.

[23] Sulistyarini. (2015). PENGEMBANGAN KARAKTER BERBASIS PANCASILA MELALUI PENDIDIKAN KEWARGANEGARAAN. JURNAL BHINNEKA TUNGGAL IKA, 2(1).

[24] Suresh, C., \& Clinton, F. (2021). Employees' identification and management control systems: a case study of modern policing. Accounting, Auditing \& Accountability Journal, 34(1), 31-53. https://doi.org/10.1108/AAAJ-04-2020-4490

[25] Wahab, A. A., \& Sapriya. (2011). Teori dan landasan pendidikan kewarganegar-aan. Bandung: Alfabeta.

[26] Wahab, R. (2016). Psikologi Belajar. Jakarta: PT RajaGrafindo Persada.

[27] Wibowo, A. (2011). Pendidikan Karakter: Strategi Membangun KarakterBangsa Berperadaban. Yogyakarta: Pustaka Pelajar.

[28] Zandvakili, E., Washington, E., Gordon, E. W., Wells, C., \& Mangaliso, M. (2019). Teaching Patterns of Critical Thinking: The 3CA Model-Concept Maps, Critical Thinking, Collaboration, and Assessment. SAGE Open, 9(4), 2158244019885142. https://doi.org/10.1177/2158244019885142 